\title{
EKONOMI ISLAM DAN POLITIK HUKUM DI INDONESIA
}

\author{
Dudi Badruzaman \\ STAI Sabili Bandung \\ badruzaman.dudi@yahoo.com
}

\begin{abstract}
Abstak - Penelitian ini akan menguraikan sejarah hubungan ekonomi dan politik Islam modern dengan hukum dalam upaya merumuskan berbagai UU ekonomi Islam. Artikel ini juga menggambarkan posisi ekonomi Islam dalam sistem hukum Indonesia sehingga akan diperoleh deskripsi bagaimana implementasi ekonomi Islam dalam perekonomian Indonesia. Penelitian ini bertujuan untuk mencari dasar bagi pengembangan hukum ekonomi Islam yang ada di dua periode, Orde Baru dan Era Reformasi. Agar instrumen-instrumen ekonomi syariah dapat dijadikan sebagai bagian penting dari mainstream kebijakan ekonomi nasional, maka perlu ada upaya sistematis dalam menciptakan desain politik ekonomi syariah. Desain ini harus mencakup tiga ranah utama, yaitu ranah regulasi dan aturan hukum, ranah penguatan dan ekspansi kelembagaan, serta ranah internalisasi nilai ekonomi syariah dalam kehidupan negara dan masyarakat.
\end{abstract}

Kata kunci: Ekonomi Islam, Politik Hukum, dan Tata Hukum

Abstract - This research will describe the history of modern Islamic economic and political relations with the law in an effort to formulate various Islamic economic laws. This article also describes the position of the Islamic economy in the Indonesian legal system so that a description of how Islamic economy can be implemented in the Indonesian economy will be obtained. This study aims to find a basis for the development of Islamic economic law in two periods, the New Order and the Reformation Era. So that Islamic economic instruments can be used as an important part of the mainstream of national economic policy, there needs to be a systematic effort to create a sharia economic political design. This design must include three main domains, namely the realm of regulation and the rule of law, the realm of institutional strengthening and expansion, and the realm of internalizing sharia economic values in the life of the state and society.

Keyword: Islamic Economics, Politics of Law, and Governance

\section{A. PENDAHULUAN}

Sejarah perkembangan ekonomi Islam modern dimulai sekitar tahun 1970an ketika munculnya kesadaran akan sebuah sistem ekonomi yang lebih berpihak kepada negara-negara muslim yang dianggap tertinggal dibandingkan dengan negara-negara Barat. Ide ini dicetuskan oleh beberapa pakar ekonomi muslim yang sebagian besar mereka 
mendapatkan pendidikan di Barat. Demikianpun, pada sekitar tahun 1940-an, ide ekonomi Islam telah memiliki akar yang cukup kuat ketika dicetuskannya beberapa lembaga keuangan non bank seperti di Malaysia dan Pakistan. ${ }^{1}$

Ekonomi Islam mendapatkan momentum ketika didirikannya Islamic Development Bank (IDB) pada tahun 1976 di Jeddah. IDB didirikan setelah sebelumnya terjadi berbagai pertemuan penting negara-negara OKI yang merumuskan perlunya sebuah alternatif sistem ekonomi baru bagi negara-negara anggota yang diawali dengan pendirian lembaga-lembaga keuangan dengan prinsip Islam.

Perkembangan ekonomi Islam dalam bentuk pendirian lembaga keuangan ini ternyata diminati banyak kalangan dan negara-negara di dunia. Beberapa negara non Islam bahkan turut serta mengadopsi model keuangan Islam seperti Amerika Serikat, Inggeris, Jerman, dll. Minat yang besar terhadap lembaga keuangan Islam ini terutama dipengaruhi oleh daya tahan perbankan Islam terhadap krisis. Sebagaimana dimaklumi bahwa dunia banyak tejerat oleh berbagai krisis keuangan dan perbankan memainkan peran

\footnotetext{
${ }^{1}$ Ausaf Ahmad, Instruments and Regulation and Control of Islamic Banks by The Central Banks. (Jeddah: Islamic Development Bank, 2013) hal. 18
}

besar dalam penciptaan krisis tersebut seperti yang pernah terjadi pada kasus suprime mortgage.

Abdullah Saeed menyatakan bahwa setidaknya ada 3 (tiga) faktor utama munculnya bank Islam yaitu: Munculnya kelompok neo-revivalis yang menyatakan bahwa bunga bank adalah riba, (2) Melimpahnya minyak di negaranegara Teluk yang berimplikasi pada peningkatan kemakmuran negara-negara di sekitarnya, dan (3) Adanya adaptasi yang dilakukan oleh beberapa negara terhadap konsep tradisional riba. ${ }^{2}$

Ide pendirian lembaga keuangan berimplikasi pada model sistem keuangan negara yang menerapkannya. Setidaknya ada 2 (dua) model sistem keuangan negara yang menerapkan ekonomi Islam, yaitu 1. Negara yang sepenuhnya menerapakan sistem keuangan Islam didalamsistem keuangannya seperti Iran, Pakistan dan Sudan, 2. Negara yang menganut sistem keuangan ganda yaitu sistem konvensional dan Islam. Model ini diterapkan di sebagian besar negara saat ini. ${ }^{3}$

Secara umum tahapan-tahapan

\footnotetext{
${ }^{2}$ Abdullah Saeed, Islamic Banking and Interest: A Study of Prohibition of Riba and Its Contemporary Interpretations, (Leiden: E.J. Brill, 2015) hal.8

${ }^{3}$ Ausaf Ahmad, Instruments and Regulation and Control of Islamic Banks by The Central Banks. (Jeddah: Islamic Development Bank, 2013) hal.32
} 
evolusi perkembangan industri keuangan syariah di dunia dapat digambarkan sebagai berikut:

1. Dekade tahun 1970an: berupa pendirian lembaga perbankan Islam dalam bentuk bank komersial syariah (commercial syariah banks), dalam bentuk produk-produk bank komersial (commercial banking products), dengan cakupan wilayah masih pada kawasan Timur Tengah (Gulf/ME).

2. Dekade tahun 1980an: berupa pendirian bank komersial syariah dan juga asuransi dan perusahaan investasi syariah commercial islamic banks, takaful - Islamic insurance, syariah investment co's). sedangkan produknya sudah mencakup pada asuransi, serta sindikasi keuangan Islam. Areanya sudah mencakup Asia Pasifik.

Dekade tahun 1990an: pendirian lembaga keuangan syariah juga diikuti oleh pendirian berbagai perusahaan asuransi, investasi, dan manajemen aset. Produkproduk yang diluncurkan sudah bertambah seperti adanya reksadana syariah. Cakupannya juga sudah mencapai Eropa dan Amerika. Dekade tahun 2000-an: ditandai dengan pendirian lembaga keuangan Islam, e-commerce, manajemen likuiditas, broker dan dealer serta instrument pasar modal Islam. Area ini sudah mencakup pasar global.

Pada waktu Indonesia memasuki abad ke-21, hukum Islam berkembang kepada bidang ekonomi yang ditandainya dengan lahirnya Bank Syariah, Asuransi Takaful, dan Pasar Modal Syariah. Paling akhir Hukum Islam sampai kepada Hukum Tata Negara dan Hukum Pidana dengan lahirnya Otonomi Daerah Aceh yang berdasarkan Syariat Islam dan berlakunya hukum cambuk di daerah tersebut. Semua sistem hukum tersebut di atas berlaku dan eksestensinya berjalan di Indonesia, menjadi bagian dari hukum nasional Indonesia. Hukum Ekonomi Islam yang merupakan bagian dari Hukum Islam adalah juga hukum nasional Indonesia, berdampingan dengan sistem hukum lainnya.

Terkait dengan model ekonomi Islam yang dianut oleh Indonesia, maka model keuangan ganda adalah pilihan dari pemerintah Indonesia. Dengan demikian, Indonesia sama halnya juga dengan mayoritas negara lainnya memperlakukan secara bertahap (gradual). Ini artinya berbagai peraturan dan produk hukum ekonomi Islam akan terus berkembang di Indonesia sesuai dengan kebutuhan atau 
desakan dari para pemangku kepentingan ekonomi Islam di Indonesia.

Secara kelembagaan sistem keuangan syariah yang diterapkan di Indonesia meliputi lembaga keuangan bank dan non bank. Kedua sistem lembaga ini sama- sama memainkan peran penting dalam percaturan ekonomi syariah di Indonesia. Keduanya juga memiliki ruang lingkup yang berbeda. Kendati berbeda, namun peran keduanya sangat menentukan dalam mencapai tujuan ekonomi syariah secara khusus dan ekonomi nasional secara umum. 4

Perkembangan ekonomi Islam yang begitu pesat menuntut kebutuhan terhadap instrumen hukum yang mendukung. Dari sinilah muncul istiah hukum ekonomi Islam. Dalam kaitan dengan ekonomi Islam, maka hukum ekonomi Islam pada satu sisi memiliki corak yang sama dengan hukum bisnis atau hukum dagang, namun pada sisi lain, akibat prinsip ekonomi Islam yang didasarkan pada sumber-sumber dari al-Quran dan hadis, maka hukum ekonomi Islam juga memiliki corak yang menunjukkan nilai-nilai-nilai Islam terhadapnya.

Hukum ekonomi Islam juga tidak dapat dipisahkan dari hukum Islam itu sendiri. Artinya, hukum ekonomi Islam

\footnotetext{
${ }^{4}$ M. Kabir Hasan and Mervyn K. Lewis, Handbook of Islamic Banking, (UK Edward Elgar Publishing Limited, 2017) hal 18
}

adalah satu bagian dari hukum Islam secara keseluruhan. Dengan demikian, maka membincangkan hukum ekonomi Islam menuntut adanya perhatian yang sama terhadap keberadaan hukum Islam itu sendiri.

Hukum ekonomi Islam biasanya lebih dikenal dengan sebutan fikih muamalah. Dalam implementasinya, prinsip fikih muamalah memiliki perbedaan dengan prinsip dalam fikih ibadah. Dalam penerapan muamalah, maka prinsip yang dipakai adalah bahwa semua praktik ekonomi / muamalah itu diperbolehkan kecuali ada dalil yang melarangnya. Ini berbeda dengan kaidah dalam fikih ibadah yaitu semua ibadah adalah haram dilakukan kecuali ada yang membolehkannya.

Ekonomi Islam memiliki keterkaitan langsung dengan politik suatu negara. Artinya, kendati setiap pemerintah (negaranegara anggota OKI khususnya) menjadikan ekonomi Islam sebagai dasar perumusan kebijakan perekonomian mereka, maka perkembangan ekonomi Islam belum akan bisa menyaingi ekonomi konvensional. Dengan kata lain, perlu didorong keberpihakan kekuasaan terhadap pengembangan ekonomi Islam secara keseluruhan, sehingga dominasi ekonomi ribawi dapat diminimalisasi.

Dengan demikian, keputusan politik 
negara memiliki pengaruh yang sangat kuat terhadap kondisi perekonomian. Wajah dan kinerja ekonomi sebuah negara, sangat ditentukan oleh mekanisme dan proses pengambilan keputusan politik yang berlaku dan disepakati oleh masyarakat di negara tersebut.

Hal ini pun sejalan dengan pernyataan mantan Menteri Keuangan Chili, Alejandro Foxley, sebagaimana dinyatakan oleh Stephan Haggard, yang menegaskan bahwa seorang ekonom tidak hanya harus paham mengenai model-model ekonomi, tetapi juga harus memahami politik, minat, konflik-konflik, serta hasrathasrat yang berkembang di masyarakat yang merupakan esensi kehidupan. Seorang ekonom harus bisa menjadi seorang politisi dengan membangun koalisi dan bekerja sama dengan orang-orang di sekeliling mereka. Pemahaman yang baik terhadap proses dan mekanisme politik, sangat menentukan keberhasilan sebuah gagasan ataupun sebuah ideologi ekonomi dalam menciptakan sistem perekonomian yang menjadikan nilai (value) yang dibawa oleh gagasan atau ideologi tersebut sebagai pondasi utamanya.

Sebagai contoh, ketika teori pengeluaran agregat menyatakan bahwa variabel-variabel yang mempengaruhi pengeluaran agregat hanya ada empat, yaitu konsumsi, investasi, pengeluaran pemerintah, dan net ekspor, dan teori tersebut diadopsi oleh kekuasaan dalam desain kebijakan ekonominya, maka bukan hal yang mudah untuk memasukkan zakat sebagai bagian penting dalam komponen pengeluaran agregat. Zakat bukan dipahami hanya sekedar kedermawanan (charity) yang tidak memiliki implikasi terhadap peningkatan kualitas pertumbuhan ekonomi, kendati faktanya memang hingga sampai saat ini, instrumen zakat terkesan masih dianggap sebagai instrumen kelas dua dalam konteks kebijakan fiskal (fiscal policy)

Agar instrumen-instrumen ekonomi syariah dapat dijadikan sebagai bagian penting dari mainstream kebijakan ekonomi nasional, maka perlu ada upaya sistematis dalam menciptakan desain politik ekonomi syariah. Desain ini harus mencakup tiga ranah utama, yaitu ranah regulasi dan aturan hukum, ranah penguatan dan ekspansi kelembagaan, serta ranah internalisasi nilai ekonomi syariah dalam kehidupan negara dan masyarakat. ${ }^{5}$

Pada ranah yang pertama, yaitu regulasi, maka keberadaan perangkat perundang-undangan beserta aturan-aturan turunannya menjadi sangat krusial untuk

\footnotetext{
${ }^{5}$ M. Abdul Mannan, Islamic Economics; Theory and Practice, (Cambridge: Houder and Stoughton Ltd.,2017) hal. 161
} 
diperhatikan. Para pemangku kepentingan (stakeholder) ekonomi syariah harus memikirkan desain regulasi yang dapat meningkatkan akselerasi peran dan pertumbuhan ekonomi syariah.Dari sisi ini, harus diakui bahwa ekonomi syariah masih jauh tertinggal. Jumlah UU-nya baru ada empat, yaitu UU No. 41/2004 tentang Wakaf, UU No. 19/2008 tentang SBSN, UU No. 21/2008 tentang Perbankan Syariah, dan UU No. 23/2011 tentang Pengelolaan Zakat. Belum lagi jika dibandingkan dengan perangkat peraturan di bawahnya, akan jauh lebih tertinggal. Oleh karena itu, advokasi kebijakan publik berkelanjutan menjadi sebuah kebutuhan yang sangat mendesak.

Ranah kedua adalah ekspansi kelembagaan yang menitikberatkan pada upaya untuk meningkatkan ukuran industri ekonomi syariah yaitu bagaimana menjadikan pangsa pasar (market share) perbankan syariah, asuransi syariah, pasar modal syariah, BMT, lembaga keuangan mikro syariah, bisa meningkat dari waktu ke waktu atau bagaimana meningkatkan angka penghimpunan dan pendayagunaan zakat, serta menciptakan sistem pendidikan ekonomi syariah yang terintegrasi dengan baik ke dalam sistem pendidikan nasional. Tentu saja, ekspansi ini akan dapat dipercepat jika pada ranah pertama, ada dukungan regulasi yang kongkret terhadap pengembangan institusi ekonomi syariah.

Ranah ketiga, internalisasi nilai-nilai ekonomi syariah kepada seluruh komponen bangsa, merupakan hal yang sangat penting dalam menciptakan cara pandang tentang bagaimana berekonomi dan berbisnis yang sesuai dengan tuntunan syariah. Penanaman nilai-nilai ekonomi syariah ini akan mempengaruhi perilaku para economic agent. Misalnya, ketika seseorang mengetahui bahwa kejujuran memiliki implikasi nilai ibadah kepada Allah, termasuk implikasi pada diterima tidaknya zakat, infak dan sedekah seseorang di hadapan Allah, maka perilaku khianat, korupsi, serta suka mengurangi takaran dan timbangan, tidak akan ia lakukan.

Penanaman nilai-nilai atau proses ideologisasi ini dapat dilakukan melalui tiga pendekatan. Pertama, aplikasi nilai Islam dalam kegiatan ekonomi dan bisnis, seperti mempraktikkan prinsip kerja sama antar pebisnis dan lembaga ekonomi syariah. Kedua, edukasi publik melalui kampanye ekonomi syariah yang efektif dan berkesinambungan, termasuk penanaman nilai-nilai ke-ekonomi syariahan sejak dini, dan ketiga, pengembangan kurikulum pendidikan ekonomi syariah pada semua level pendidikan, terutama pendidikan tinggi, baik sarjana maupun pascasarjana. Jika 
pendekatan ini dapat dilakukan dengan baik disertai perhatian yang maksimal pada tiga ranah ekonomi syariah yang teah dijelaskan di atas, maka perkembangan ekonomi syariah di Indonesia akan bisa memberikan kontribusi yang positif bagi pembangunan bangsa Indonesia.

\section{Metode Penelitian}

Metode yang digunakan dalam penelitian ini adalah metode content analysis (analisis isi), yaitu suatu metode penelitian pemikiran yang bersifat normatif ${ }^{6}$. Data-data yang dipakai dalam penelitian ini meliputi data primer dan data skunder. (a) Data primer, Yaitu bahan hukum yang mengikat yang terdiri dari buku-buku (b) Data skunder yaitu kitabkitab dan buku-buku yang relevan dengan masalah yang diteliti yang menunjang. Soejono Soekanto, Pengantar Penelitian Hukum.

Teknik pengumpulan data yang diperlukan dalam penelitian ini adalah studi kepustakaan yaitu mempelajari bukubuku yang berhubungan dengan masalah yang dibahas. Untuk mengetahui hubungan data yang telah diperoleh maka diperlukan analisis data menggunakan data sebagai berikut: (a) Mengumpulkan data yang diperlukan seperti, teori-teori yang berkaitan dengan judul penelitian (b)

\footnotetext{
${ }^{6}$ Dede Rosyada, Hukum islam Dalam Pranata Sosial (Jakarta: Rajawali Pres, 1995), hlm. 88.
}

Mengklasifikasikan data baik dari bahan hukum primer maupun bahan hukum skunder sesuai dengan permasalahan yang diajukan. (c) Menganalisa dan menyimpulkan hasil data yang telah diklasifikasi berdasarkan permasalahan yang diajukan guna meraih tujuan yang ingin dicapai penulis dalam penelitian ini.

\section{B. PEMBAHASAN}

1. Hukum Ekonomi Islam dalam Tata Hukum Indonesia

Sebelum dijelaskan tentang hukum ekonomi Islam dalam tata hukum Indonesia, maka perlu dikaji terlebih dahulu mengenai tata hukum yang ada di Indonesia. Dari perspektif sistem hukum nasional, bentuk negara kesatuan RI bukan sekedar fenomena yuridis-konstitusional, tetapi merupakan suatu yang oleh Friedman disebut sebagai "people attitudes" yang mengandung hal-hal seperti di atas yakni:keyakinan (beliefs), nilai (values), ide-ide (ideas), dan harapan (expectations). Paham negara kesatuan bagi bangsa Indonesia adalah suatu keyakinan, suatu nilai, suatu cita dan harapan-harapan. Dengan unsur-unsur tersebut, paham negara kesatuan bagi rakyat Indonesia mempunyai makna ideologis bahkan filosofis, bukan sekedar yuridis-formal. Dengan perkataan lain, sistem hukum nasional merupakan 
pengejawantahan unsur budaya yang terintegrasi dengan baik dan dilandasai semangat kebangsaan.

Di dunia, setidaknya terdapat beberapa sistem hukum yaitu: Hukum Islam (Islamic Law), Civil Law, Common Law, Adatrech, Socialist Law, Sub-Sahara African Law dan Far East Law. ${ }^{21}$ Sistem hukum Indonesia mengikuti tradisi Civil Lawyang ciri utamanya adalah peraturan perundang-undangan yang terkodifikasi. Sementara itu hukum Islam walaupun mempunyai sumber-sumber tertulis pada al-Qur'an, Sunnah dan pendapat para fuqaha (doktrin fikih) pada umumnya tidak terkodifikasi dalam bentuk buku perundang-undangan yang mudah dirujuk. Oleh karena itu, hukum Islam di Indonesia seperti halnya juga hukum adat, sering dipandang sebagai hukum tidak tertulis dalam bentuk perundangundangan. ${ }^{7}$

Dengan demikian, sistem hukum di Indonesia menganut beberapa sistem hukum, yaitu:

1. Hukum Adat yaitu norma-norma yang hidup dimasyarakat dan mempunyai sanksi kalau tidak diikuti, adalah hukum asli Indonesia.

2. Hukum Islam yang datang dibawa

\footnotetext{
${ }^{7}$ Rifyal Ka'bah, Kodifikasi Hukum Islam Melalui Perundang-Undangan Negara di Indonesia, Majalah Hukum Suara Uldilag, Vol.II No.5.
}

pedagang-pedagang yang

mengembangkan agama Islam, sumber hukumnya Qur'an dan Hadis, serta Ijtihad. Daerah- daerah yang kuat Islamnya dan umat Islam pada umumnya di Indonesia tunduk pada Hukum Islam. Hukum Islam pada mulanya hanya berkembang pada Hukum Keluarga seperti perkawinan, perceraian dan warisan.

Hukum Civil Law yang berasal dari Code Napoleon Perancis menyebar sampai Belanda, dan dari Belanda mengalir ke Indonesia yang pada mulanya berlaku untuk orang Eropa di Hindia Belanda. Sistem hukum ini menganggap bahwa hukum itu adalah peraturan perundangundangan. Pada tahun 1970-an masuk pula ke Indonesia unsur-unsur Sistem Hukum Common Law. Pengaruh Common Law ini ada pada Undang-undang Perseroan Terbatas, Undang- Undang Lingkungan Hidup, Undang-undang Perlindungan Konsumen dan cara memutus majelis hakim di pengadilan.

Oleh karena itu, pendekatan yang dapat digunakan sebagai upaya mentransformasikan hukum ekonomi Islam ke dalam hukum nasional adalah meminjam teori hukumnya Hans Kelsen (Stufenbau des Rechts). Menurut teori ini, berlakunya suatu hukum harus dapat dikembalikan kepada hukum yang lebih 
tinggi kedudukannya yaitu:

1. Ada cita-cita hukum (rechtsidee) yang merupakan norma abstrak.

2. Ada norma kongkret (concrete norm), sebagai hasil penerapan norma antara atau penegakannya di pengadilan.

Berkaitan dengan kondisi hukum Indonesia di atas, maka keberadaan hukum ekonomi Islam setidaknya dimulai ketika hukum Islam telah diakui dalam tatanan hukum Indonesia. Pengakuan ini ditunjukkan dengan lahirnya Kompilasi Hukum Islam (KHI) pada tahun 1991. Meskipun cakupan KHI masih sebatas pada permasalahan hukum keluarga, namun momentum ini setidaknya memberikan pengaruh mendalam bagi lahirnya Kompilasi Hukum Ekonomi Islam yang bisa dijadikan sebagai ikon hukum ekonomi Islam di Indonesia. ${ }^{8}$

Hukum ekonomi Islam yang lahir di Indonesia setidaknya diawali dari gerakan ekonomi Islam dunia. Sejumlah ulama dan cendekiawan muslim Indonesia mulai melihat fakta bahwa sistem ekonomi kapitalis dan sosialis tidak bisa diharapkan terlalu banyak, karena telah terbukti dampak buruk dari kedua sistem ekonomi ini. Mereka pun berfikir perlu

\footnotetext{
${ }^{8}$ Euis Nurlaelawati, Modernization, Tradition and Identity The Kompilasi Hukum Islam and Legal Practice in the Indonesian Religious Courts, Amsterdam: Amsterdam University Press, 2010.
}

dikembangkannya sistem ekonomi alternatif dari dua sistem ekonomi tersebut. Setidaknya ada dua upaya yang dilakukan,Ada norma an yaitu :

1. Mengkombinasikan dua sistem ekonomi tersebut ke dalam sistem ekonomi baru, seperti yang telah dikembangkan oleh China selama dua dekade ini; dan

2. Memunculkan sistem ekonomi yang benar-benar berbeda dari semangat kedua sistem ekonomi terdahulu.

Ternyata upaya yang kedua diatas yang menjadi pilihan sebagai pintu masuk bagi sistem ekonomi Islam di Indonesia. Pada mulanya pihak-pihak yang meyakini dan memperjuangkan sistem ekonomi Islam sebagai sistem ekonomi alternatif yang berkeadilan dianggap sebagai bahan cemoohan. Sikap optimis bahwa sistem ekonomi Islam dapat menutupi kelemahan dan kekurangan sistemekonomi kapitalis atau sosialis/komunis dianggap sebagai ide yang berlebihan dan bahkan dianggap sebagai sebuah pernyataan bombastisidealistis. Kondisi seperti ini merupakan fakta sejarah yang terjadi di negara-negara Islam, tidak terkecuali di Indonesia. Sampai dengan awal tahun 1990-an cemoohan dan pandangan sinis terhadap pihak-pihak yang gigih memperjuangkan sistem ekonomi syariah masih nyaring 
terdengar, namun pelan-pelan perjuangan untuk pengakuan sistem ekonomi syariah sebagai sistem ekonomi alternatif mulai diterima.

\section{Relevansi Politik Dengan Hukum} Ekonomi Islam di Indonesia

Kaitan hukum dengan politik dalam studi hukum disebut dengan studi politik hukum.Dalam politik hukum ada 2 (dua) dimensi yang tak terpisahkan satu dengan lainnya yaitu dimensi filosofis-teoritis dan dimensi normatif- operasional.

Kelahiran hukum ekonomi Islam, juga didukung oleh kenyataan bahwa Pengadilan Agama yang telah lama diakui eksistensinya di Indonesia, masih belum mempunyai kitab hukum yang dijadikan standarisasi bagi hakim dalam memutus perkara ekonomi selevel KUHPdt. Kondisi ini bisa menyulitkan para hakim dalam memutuskan perkara terkait ekonomi Islam.

Pada sisi lain, adanya aspirasi umat Islam yang menghendaki pemberlakuan ekonomi syariah sebagai hukum positif juga harus diimplementasikan dalam bentuk politik hukum. Politik hukum yang dilakukan tersebut diimplementasikan dalam kebijakan politik di Indonesia memberikan dukungan pertama kali dengan legislasi UU No. 7 Tahun 1992 tentang Perbankan, yang memungkinkan beroperasinya bank dengan sistem bagi hasil (pasal 6). UU ini kemudian dirubah dengan UU No. 10 Tahun 1998 tentang Perubahan atas UU No.7 Tahun 1992 tentang Perbankan, yang secara eksplisit menyebutkan istilah "bank berdasarkan prinsip syariah".

Terbitnya UU No. 10 Tahun 1998 tersebut, menjadi moment penting bagi dimulainya gerakan ekonomi syariah di Indonesia. Setelah itu, gerakan ekonomi syariah terus digaungkan dan diperjuangkan oleh para aktivis ekonomi syariah, baik para ulama, akademisi maupun praktisi tidak kenal lelah. Gerakan ini pun menggelinding bagaikan gerakan bola salju yang semakin membesar yang tidak dapat terbendung lagi. Terus dikawal oleh lembaga-lembaga yang lahir dari gerakan ini, seperti Dewan Syariah Nasional Majelis Ulama Indonesia (DSNMUI), Masyarakat Ekonomi Syariah (MES), Ikatan Ahli Ekonomi Islam (IAEI), dan sebagainya. Gerakan dan perjuangan ekonomi syariah ini kemudian melahirkan lembaga-lembaga teknis di lingkungan pemerintah, seperti Direktorat Perbankan Syariah di Bank Indonesia, Direktorat Pembiayaan Syariah di Departemen Keuangan, dan berbagai biro di Badan Pengawas Pasar Modal (BAPEPAM).

Gerakan ini juga melahirkan sejumlah undang-undang dan peraturan 
perundangan lainnya, misalnya UndangUndang Nomor 21 Tahun 2008 Tentang Perbankan Syariah, Undang-Undang Nomor 19 Tahun 2008 Tentang Surat Berharga Syariah Negara (SBSN), Berbagai Peraturan Bank Indonesia, Peraturan Bapepam, dan peraturanperaturan lainnya. Di samping itu, gerakan ini juga melahirkan lembaga-lembaga keuangan syariah meliputi: perbankan syariah, asuransi syariah, pegadaian syariah, pembiayaan syariah, pasar modal syariah, bursa komoditi syariah, bisnis syariah, dan sebagainya.

Lahirnya Undang Undang Nomor 3 Tahun 2006 Tentang Perubahan Undang Undang Nomor 7 Tahun 1989 Tentang Peradilan Agama yang memberikan kewenangan kepada Peradilan Agama dalam menyelesaikan sengketa ekonomi syariah adalah merupakah langkah politik hukum yang luarbiasa dalam melengkapi kelembagaan "hukum" untuk mewujudkan gerakan ekonomi syariah di Indonesia, sehingga kini gerakan ekonomi syariah riil mendapatkan dukungan dari berbagai pihak.

$$
\text { Selain peraturan perundang- }
$$
undangan di atas, maka upaya politik hukum lain yang dilakukan adalah proses legislasi dengan menyusun Rancangan Undang-Undang (RUU) yang diajukan kepada badan legislatif (DPR). Legislasi ini cukup menarik dan dipandang penting setidaknya disebabkan karena adanya beberapa faktor pendukung antara lain:

1. Legislasi bisa menjadi unifikasi yang produktif bagi berbagai aliran mazhab yang digunakan di Indonesia terkait masalah ekonomi.

2. Subtansi hukum ekonomi Islam yangmapantelah ditunjukkan dengan penggunaan produk fikih dari beberapa imam madzhab di Indonesia.

3. Produk legislasi adalah produk politik, sehingga untuk berhasil memperjuangkan legislasi hukum Islam harus mendapatkan dukungan suara mayoritas di lembaga pembentuk hukum. Fakta politik juga menunjukkan bahwa meskipun aspirasi politik Islam bukan mayoritas di Indonesia, namun memperhatikan konfigurasi politik dalam dasawarsa terakhir cukup memberi angin segar bagi lahirnya produk-produk hukum nasional yang bernuansa Islami.

Hukum ekonomi Islam yang diusung ke jalur legislasi diformat dalam bentuk bentuk buku atau kitab undang-undang yang tersusun rapi, praktis dan sistematis. Materinya juga bukan hanya berasal dari satu madzhab fikih saja, melainkan dipilih dan di-tarji $<h$ (menguatkan salah satu dari beberapa pendapat madzhab) dari berbagai pendapat 
madzhab fikih yang lebih sesuai dengan kondisi dan kemaslahatan yang menghendaki. Hal ini secara otomatis menghilangkan sikap $\left.\left.t a^{\prime} a s\right\} s\right\} u b$ (fanatik) madzhab, seperti fikih madzhab Hanafi yang dipakai di kerajaan Turki pada tahun 1876, fikih madzhab Syafi'i yang dipakai di wilayah Mesir dan Suriah serta fikih madzhab Imam Malik yang dipakai di Irak.

Meskipun demikian, legislasi sebagai produk politik hukum juga memiliki berbagai tantangan, seperti: ${ }^{9}$

1. Perbedaan pendapat di kalangan intern umat Islam sendiri yang sebagian menolak gagasan legislasi.

2. Perbedaan pendapat di kalangan intern Islam mengenai subtansi hukum (ekonomi syariah) yang yang akan diundangkan kemungkinan masih ada ikhtila $<f$ (ada perbedaan pendapat).

3. Adanya resistensi dari kalangan non muslim yang menganggap legislasi hukum Islam "ekonomi syariah" di Indonesia akan menempatkan mereka (seolah-olah sebagai warga negara kelas dua) dan ini juga dipicu oleh sikap dan pernyataan sebagian gerakan Islam sendiri yang justru kontra produktif bagi perjuangan hukum Islam.

Secara umum, legislasi hukum ekonomi Islam di Indonesia memiliki

\footnotetext{
${ }^{9}$ Jazuni, Legislasi Hukum Islam di Indonesia, (Bandung: Citra Aditya Bakti, 2015)hlm.29

beberapa hal positif, yaitu:

a. Tingkat prediktibilitas tinggi yaitu adanya gambaran hukum secara pasti sebelum suatu perbuatan itu dilakukan masyarakat, sehingga sudah bisa diprediksi akibat hukumnya.

b. Perundang-undangan juga memberikan kepastian mengenai nilai yang dipertaruhkan. Sekali suatu peraturan dibuat, maka menjadi pasti pula nilai yang hendak dilindungi oleh peraturan tersebut. Oleh karena itu, orang tidak perlu lagi memperdebatkan apakah nilai itu diterima atau tidak. Sedangkan menurut ulama fikih, sisi positif hukum Islam dalam bentuk perundang-undangan antara lain:

1. Memudahkan para praktisi hukum untuk merujuk hukum sesuai dengan keinginannya. Kitab-kitab fikih yang tersebar di dunia Islam penuh dengan perbedaan pendapat yang kadang-kadang membingungkan dan menyulitkan. Dengan adanya undang-undang yang mengatur bidang ekonomi syariah, para hakim/praktisi hukum tidak perlu lagi mentarjih berbagai pendapat dalam literatur fikih.

2. Mengukuhkan fikih Islam dengan mengemukakan pendapat 
paling kuat. Fikih Islam penuh dengan perbedaan pendapat, bukan saja antar madzhab, tetapi juga perbedaan pendapat antar ulama dalam madzhab yang sama, sehingga sulit untuk menentukan pendapat terkuat dari sekian banyak pendapat dalam satu madzhab. Keadaan seperti ini sangat menyulitkan hakim (apalagi orang awam) untuk memilih hukum yang akan diterapkan, belum lagi meneliti apakah orang yang berperkara tersebut bermadzhab Hanbali atau Syafi'i, sehingga hasil ijtihad Madzhab Hanafi atau Maliki tidak diterapkan kepadanya. Dalam kaitan ini, undang- undang yang sesuai dengan pendapat yang kuat akan lebih praktis dan mudah dirujuk oleh para hakim, apalagi di zaman modern ini para hakim pada umumnya belum memenuhi syaratsyarat mujtahid, sebagaimana yang ditetapkan oleh ulama.

3. Menghindari sikap taklid madzhab di kalangan praktisi hukum, yang selama ini menjadi kendala dalam lembaga-lembaga hukum.

4. Menciptakan unifikasi hukum bagi lembaga-lembaga peradilan. Apabila hukum dalam suatu negara tidak hanya satu, maka akan muncul perbedaan keputusan antara satu peradilan dengan peradilan lainnya. Hal ini bukan saja membingungkan umat, tetapi juga menganggu stabilitas keputusan yang saling bertentangan antara satu pengadilan dengan pengadilan lain.

Kendati memiliki nilai positif perlu juga diperhatikan beberapa hal negatif yang bisa saja muncul dari sebuah proses legislasi seperti:

1. Munculnya kekakuan hukum, sedangkan manusia dengan segala persoalan kehidupannya senantiasa berkembang, dan perkembangan ini seringkali tidak diiringi dengan hukum yang mengaturnya. Dalam persoalan ini ulama fikih menyatakan,"hukum bisa terbatas, sedangkan kasus yang terjadi tidak terbatas". Di sisi lain, fikih Islam tidak dimaksudkan berlaku sepanjang masa, tetapi hanya untuk menjawab persoalan yang timbul pada suatu kondisi, masa, dan tempat tertentu. Oleh karena itu, hukum senantiasa perlu disesuaikan dengan kondisi, tempat, zaman yang lain. Tidak jarang ditemukan bahwa peristiwa yang menghendaki hukum lebih 
cepat berkembang dibandingkan dengan hukum itu sendiri. Oleh karena itu. Adanya undangundang bisa memperlambat perkembangan hukum itu sendiri.

2. Mandegnya upaya ijtihad.

3. Munculnya persoalan taklid baru.

4. Mengabaikan perbedaan-perbedaan atau ciri-ciri khusus yang dimiliki masing-masing mazhab.

Meskipun terdapat berbagai tantangan, namun produk hukum ekonomi Islamdalam bentuk legislasi telah hadir di Indonesia dengan pembuatan Kompilasi Hukum Ekonomi Syariah (KHES).

\section{KESIMPULAN}

Perkembangan ekonomi Islam tidak hanya diwujudkan ke dalam aspek keuangan seperti lembaga perbankan. Di dalam kajian ekonomi Islam, banyak instrumen lainnya yang penting dan juga memerlukan dukungan yuridis yang kuat. Dukungan yang yuridis yang dimaksud adalah ketersediaan undang-undang yang akomodatif dan aspiratif serta mentransformasikan dari konsep menjadi aplikasi praktis dan sesuai dengan kondisi negara. Dalam penjelasan sebelumnya disebutkan bahwa dalam perkembangan kontemporer, konsep ekonomi Islam masih didominasi dengan penerapan prinsip
Islam dalam bidang keuangan terutama perbankan. Dominasi ini tidak seharusnya melupakan instrumen ekonomi Islam lainnya karena jika dikaitkan dengan politik dan produk hukum, maka semua aspek dan instrumen ekonomi Islam tersebut harus bisa dilihat secara komprehensif.

\section{DAFTAR PUSTAKA}

Abdullah Saeed, Islamic Banking and Interest: A Study of Prohibition of Riba and Its Contemporary Interpretations, Leiden: E.J. Brill, 2015

Abdullah Saeed, Islamic Banking and Interest: A Study of Prohibition of Riba and Its Contemporary Interpretation, Boston: Brill, 2014.

Ausaf Ahmad, Instruments and Regulation and Control of Islamic Banks by The Central Banks. Jeddah: Islamic Development Bank, 2013.

Barry Clark, Political Economy: A Comparative Approach, London: Praeger, 2010.

Euis Nurlaelawati, Modernization, Tradition and Identity The Kompilasi Hukum Islam and Legal Practice in the Indonesian Religious Courts, 
Amsterdam: Amsterdam University Press, 2010.

Hasbi Hasan, Pemikiran dan Perkembangan Hukum Ekonomi Syariah di Dunia Islam Kontemporer, Depok: Gratama Publishing, 2011.

Jane Erick Lane dan Hamadi Redissi, Religion anad Politics: Islam and Muslim Civilization (Burlington: Ashgate Publishing Company, 2016.

Jazuni, Legislasi Hukum Islam di Indonesia, Bandung: Citra Aditya Bakti, 2015.

Jurnal Mimbar Hukum,No.56 Tahun XIII, Al-Hikmah dan DITBINBAPERA Islam, Jakarta, 2012.

Jurnal Mimbar Hukum, No. 49 Tahun XI,

Al-Hikmah dan DITBINBAPERA

Islam, Jakarta, Juli-Agustus 2013.

M. Abdul Mannan, Islamic Economics;

Theory and Practice, Cambridge:

Houder and Stoughton Ltd.,2017.
M. Kabir Hasan and Mervyn K. Lewis, Handbook of Islamic Banking, UK Edward Elgar Publishing Limited, 2017.

M.B.Hendrie Anto, Pengantar

Ekonomika

Maha-Hanaan Balala, Islamic Finance and Law: Theory and Practice in a Globalized World London: I.B Tauris, 2011.

Masudul Alam Choudhury, "Regulation in The Islamic Political Economy", dalam jurnal J.KAU: Islamic Econ, (2017): vol. 12, No.1.

Muhammad 'Usman Tsabir, al-Mu'amalat al-Maliyah al-Mu'ashirah fi al-Fiqh al-Islamiy, Yordan: Dar al-Nafais, 2018.

Rifyal Ka'bah, Kodifikasi Hukum Islam Melalui Perundang-Undangan Negara di Indonesia, Majalah Hukum Suara Uldilag, Vol.II No.5. 